Egyptian Journal of Aquatic Biology \& Fisheries

Zoology Department, Faculty of Science,

Ain Shams University, Cairo, Egypt.

ISSN $1110-6131$

Vol. 24(3): $311-322$ (2020)

www.ejabf.journals.ekb.eg

\title{
Origin of Invasive Fish Species, Peacock Bass Cichla Species in Lake Telabak Malaysia Revealed by Mitochondrial DNA Barcoding
}

\author{
Aliyu G. Khaleel ${ }^{1,2}$, Syafiq A. M. Nasir ${ }^{1}$, Norshida Ismail ${ }^{1}$, \\ and Kamarudin Ahmad-Syazni ${ }^{1, *}$ \\ ${ }^{1}$ School of Animal Science, Faculty of Bioresources and Food Industry, Universiti Sultan \\ Zainal Abidin, Besut Campus, 22200 Besut, Terengganu, Malaysia. \\ ${ }^{2}$ Department of Animal Science, Faculty of Agriculture and Agricultural Technology, Kano \\ University of Science and Technology, Wudil, P.M.B. 3244 Kano State, Nigeria. \\ *Corresponding author: ahmadsyazni@unisza.edu.my
}

\section{ARTICLE INFO}

Article History:

Received: Nov. 18, 2019

Accepted: April 27, 2020

Online: May 2020

Keywords:

Peacock bass, Invasive species, mitochondrial DNA barcoding, Lake Telabak

\section{ABSTRACT}

Peacock bass (Perciformes, Cichlidae, Cichla) are multi-coloured and highly predatory fish originated from Amazonian region. The species was deliberately introduced into Malaysia freshwater bodies by anglers in the early 1990's for sport fisheries. In this recent study, we found the population of peacock bass in Lake Telabak, a man-made lake in Besut, Terengganu. Using mitochondrial DNA analysis approach, the origin and taxonomy of peacock bass in the lake were clarify. A total of forty fishes were sampled from Lake Telabak for the analysis. Haplotype was detected among all samples. The current study revealed that Cichla spp. in Lake Telabak are closer to Cichla ocellaris (Bloch and Schneider, 1801) with a sequence similarity of $99.72 \%$ as blasted at the National Center for Biotechnology Information (NCBI) database. The evolutionary history inferred using the maximum likelihood method in the molecular phylogenetic analysis also confirmed the species as C. ocellaris, but no record found concerning their origin. The Tasik Telabak peacock bass also match with the Cichla temensis which is traced to the Amazonas and Parà states of Brazil (Manaus, Novo Airão, Tapajós and Tefé).

\section{INTRODUCTION}

Human interference in the movement of living organisms across different continents of the world has caused profound changes in both the ecology of guest species and the native communities (Callaway and Maron, 2006; Yong et al., 2014; Havel $\boldsymbol{e t}$ al., 2015; Fazhan et al., 2017). The rate of increase and the measure of these relocation is quickly becoming a major concern for ecologists, resource managers and conservation biologists around the globe largely because biological invasion or introduction of nonnative fishes may cause danger and create additional threats to native biodiversity (Dudgeon, 2003; Rahim et al., 2013; Gubiani et al., 2018; Reid et al., 2018). 
Malaysia is well known for its large number of flora and fauna mega diversity (Nafis et al., 2001; Chong et al., 2010; Paknia et al., 2015). However, like other countries of the globe, Malaysia has suffered from negligent introduction of invasive species, primarily for agriculture and livestock production (Department of Fisheries Malaysia, 2010; Rahim et al., 2013). Cichla spp. popularly known as peacock bass, are voracious predator fish with wide prey range, threatening the native fishes including endemic species (Novaes et al., 2004; Agostinho et al., 2005; Reiss et al., 2012; Marques et al., 2016). According to Khairul Adha (2006), peacock bass is an invasive species that was intentionally introduced and released by some anglers into lake in the early 1990s for sport fishing in Peninsular Malaysia. Recently, a few specimens identified as peacock bass were discovered for the first time in the Lake Telabak, located in Besut, Terengganu, East Coast of Peninsular Malaysia. The lake is important for socioeconomic activities where the fish cage culture being introduce, as well as water sources for rice field activity. Furthermore, the lake become the recreational spot for fishing and family activities. The origin, taxonomy and introduction of Cichla spp. in Lake Telabak still remain unclear.

Analysis of mitochondrial DNA is a useful tool for molecular genetic studies with various applications in genetic diversity (Ahmad-Syazni et al., 2017; Ha et al., 2017; Khaleel et al., 2019) and species identification (Li et al., 2019; Golani et al., 2019). Genetic information and specific taxonomy is essential for controlling introduced Cichla spp. populations, especially those that are now invasive and a continuous part of existing species in Lake Telabak. Due to the high complexity in the Cichla genus, there is a wide range of ambiguity regarding their taxonomic identifications and descriptions morphologically (Golani $\boldsymbol{e t}$ al., 2019). However, based on the idea of DNA barcoding, a short defined sequence can differentiate individual species due to the fact that genetic diversity between species surpassed within species (Hebert et al., 2004). In addition, cytochrome c oxidase I (COI) of the mitochondrial gene with sequence diversity in a 650 base pair (bp) fraction was believed to generates powerful species-level resolution for various animal populations including birds, fish and insects (Hebert et al., 2004; Ward et al., 2005; Hajibabaei et al., 2006; Golani et al., 2019; Granato et al., 2019). The aim of this study was to provide a scientific information regarding the origin, taxonomy and introduction of Cichla spp. in Lake Telabak by analysing phylogenetic relationship using COI fraction of mitochondrial DNA barcoding.

\section{MATERIALS AND METHODS}

General flowchart of the entire experimental methods carried out in current study including sampling, DNA extraction, polymerise chain reaction (PCR), sequencing, DNA barcoding and data analysis were given below (Figure 1).

\section{Sampling}

A total of forty samples of the peacock bass were successfully collected from Lake Telabak East Coast of Peninsular Malaysia (Figure 2) from September 2018 to February 2019. Approximately $1 \mathrm{~cm}$ of tail tissue was removed with scissors and preserved in a sterile $1.5 \mathrm{ml}$ tube containing $95 \%$ ethanol. 


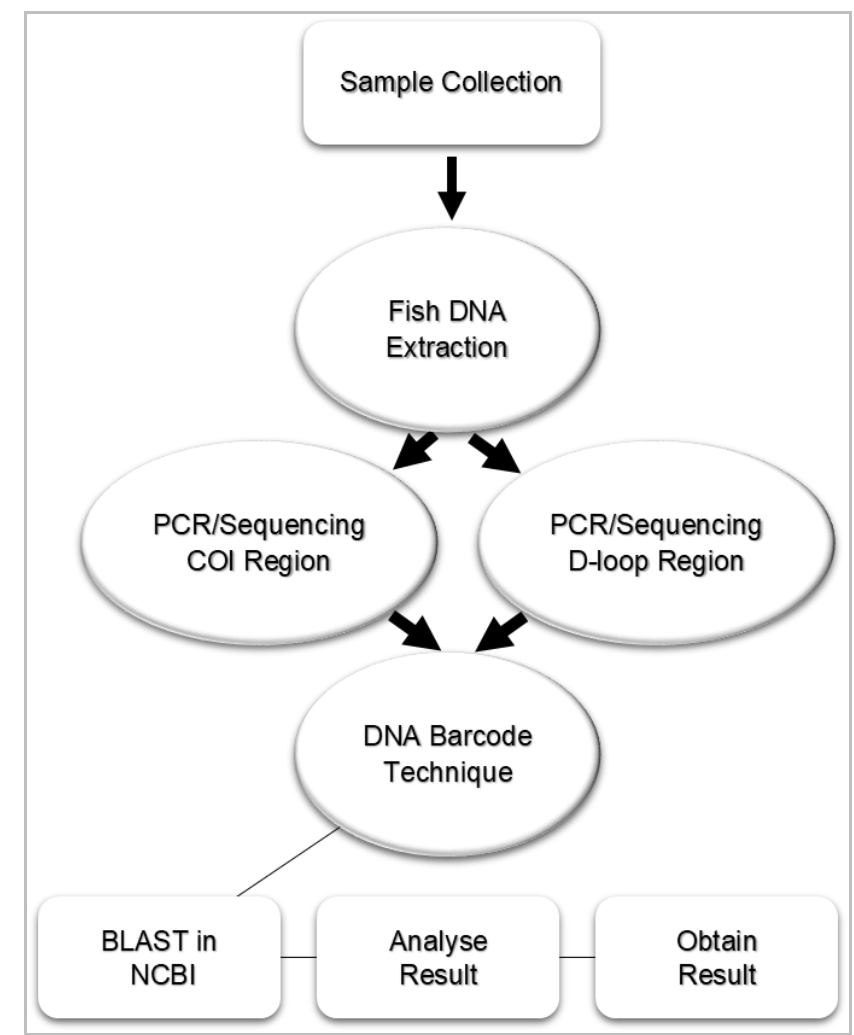

Figure 1. The overall summary of methodology flowchart

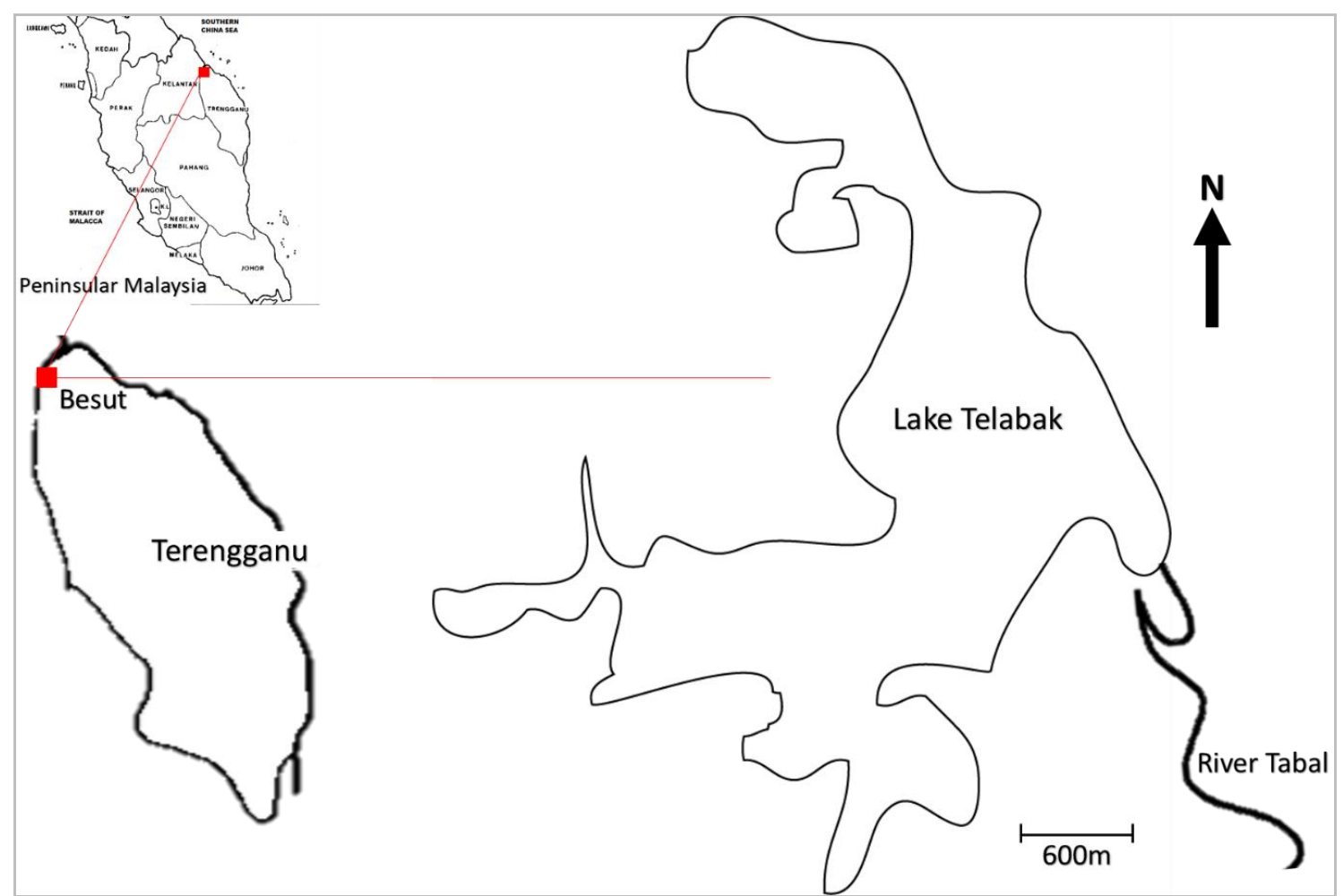

Figure 2. Location map showing the samples collection site of peacock bass in Lake Telabak, East Coast of Peninsular Malaysia (5³7'56.9"N 102²8'24.5"E) 


\section{DNA Extraction, Amplification and Sequencing}

The total genomic DNA of peacock was isolated using Favorgen DNA extraction Kit (Favorgen Biotech Corp., Ping-Tung 908, Taiwan) following manufacturer's instructions. The partial COI gene of mitochondrial DNA was amplified by PCR using the universal primers COI-Fish2 F (5'TCGACTAATCATA AAGATATCGGCAC3') and COI-Fish2 R (5'ACTTCAGGGTGACCGAAGAATCAGAA 3') by Ward $\boldsymbol{e t}$ al. (2005). Another set of primer tPro2 (5'ACCCTAACTCCCAAAGC3') and HN-20 (3'GT GTTATGCTTTAGTTAAGC5') (Lee et al., 1995; Palumbi, 1996) was used for the amplification of D-loop region. For both COI and D-loop region, the PCR was carried out in a $25 \mu \mathrm{l}$ reaction volume containing $18.2 \mu \mathrm{l}$ sterile distilled water, $2.5 \mu \mathrm{l}$ Taq buffer, 2.0 $\mu \mathrm{l} \mathrm{dNTP}$ Mix $(2.5 \mathrm{mM}), 0.5 \mu \mathrm{l}$ of each primer $(10 \mu \mathrm{M}), 0.3 \mu \mathrm{l}$ of $5 \mathrm{unit} / \mu \mathrm{l}$ Taq polymerase (TaKaRa) and $1 \mu \mathrm{l}$ template DNA (1-50 ng/ $\mu \mathrm{l})$ on a thermal cycler PCR machine Veriti 96 Well Thermal Cycler (Applied Biosystem, California, USA), under the following thermal cycling conditions. Initial denaturation at $95{ }^{\circ} \mathrm{C}$ for $5 \mathrm{~min} ; 35$ cycles including denaturation at $95{ }^{\circ} \mathrm{C}$ for $30 \mathrm{sec}$, annealing at $\left(50{ }^{\circ} \mathrm{C}, \mathrm{COI}\right)$ and $52{ }^{\circ} \mathrm{C}$, D-loop) for $30 \mathrm{sec}$ and elongation at $72{ }^{\circ} \mathrm{C}$ for $10 \mathrm{~min}$; followed by a final extension for $10 \mathrm{~min}$ at $72{ }^{0} \mathrm{C}$ and the PCR product was maintained at $4{ }^{0} \mathrm{C}$. Sequencing was succeeded using BigDye Terminator v3.1 cycle sequencing kit (Applied Biosystems) following manufacturer's instructions, performed on an ABI Prism 3730xl Genetic Analyzer (Applied Biosystems).

\section{Data Analysis}

Forty COI and ten D-loop sequences (current study) were aligned and edited using ClustalW multiple sequence alignment program in MEGA 7 (Kumar et al., 2016). DnaSP software was used to determine the variable sites among the sequence (Librado and Rozas 2009). To discover the origin of Cichla spp., the haplotype discovered in the present study was queried using basic local alignment search tool (BLAST) against NCBI nucleotide database. A top species match was identified with a sequence similarity of at least $>99 \%$ to avoid false positives. Other haplotypes closely related to Cichla spp. were also downloaded from NCBI were included to compare sequence variation; and construct a phylogenetic analysis using Hasegawa-Kishino-Yano model HYK-1 (Hasegawa et al., 1985) in MEGA 7 (Kumar et al., 2016).

\section{RESULTS}

\section{Sequence Alignment, Variation and Blast Search}

A total of $617 \mathrm{bp}$ of COI and $857 \mathrm{bp}$ of D-loop mitochondrial DNA were obtained after deletion of low quality nucleotides at the 5' and 3' ends. Only one haplotype obtained among the forty COI sequences $\left(\mathrm{T}_{1}\right)$ and one haplotype from ten D-loop sequences $\left(T_{2}\right)$ used in the current study. The $T_{1}$ and $T_{2}$ BLAST search sequence match results showed highest percentage identity with three $C$. ocellaris sequences as shown in Table 1 below. The result revealed extremely low sequence variation between $T_{1}$ and two $C$. ocellaris and one $C$. temensis with nucleotide variation of single base pair between each $C$. ocellaris as highlighted in Table 2. $\mathrm{T}_{2}$ haplotype of D-loop also showed higher sequence variation with 3 gaps in nucleotide position when compared to the previous studies sequence haplotypes of Cichla spp. (Table 2). 
Table 1. BLAST sequence match showing different max score and percentage identity between Cichla spp. COI and D-loop genes of mitochondrial DNA of the current study and previous studies obtained from NCBI

\begin{tabular}{|c|c|c|c|c|}
\hline \multicolumn{5}{|c|}{ Lake Telabak Cichla spp. COI gene } \\
\hline AC. No. & Species name & Max score & $\%$ ID & Reference \\
\hline KU878410 & Cichla ocellaris & 1147 & 99.68 & *Lin et al. (2016) \\
\hline KR150863 & Cichla ocellaris & 1146 & 99.72 & *Musilova and Starostova (2015) \\
\hline FJ440622 & Cichla temensis & 1127 & 99.84 & Ardura et al. (2010) \\
\hline KF771234 & Cichla orinocensis & 1070 & 98.04 & *Carvalho (2013) \\
\hline AY662781 & Cichla temensis & 966 & 95.00 & Sperks and Smith (2004) \\
\hline MF122533 & Monopterus albus & Nil & Nil & *Chen and He (2017) out-group \\
\hline \multicolumn{5}{|c|}{ Lake Telabak Cichla spp. D-loop gene } \\
\hline KU878410 & Cichla ocellaris & 1531 & 98.95 & *Lin et al. (2016) \\
\hline KR150863 & Cichla ocellaris & 1530 & 98.95 & *Musilova and Starostova (2015) \\
\hline DQ778662 & Cichla temensis & 966 & 95.00 & Reno et al. (2006) \\
\hline
\end{tabular}

Table 2: Sequence variations of aligned 6 COI haplotypes and 3 D-loop haplotypes genes of mitochondrial DNA of Cichla spp.

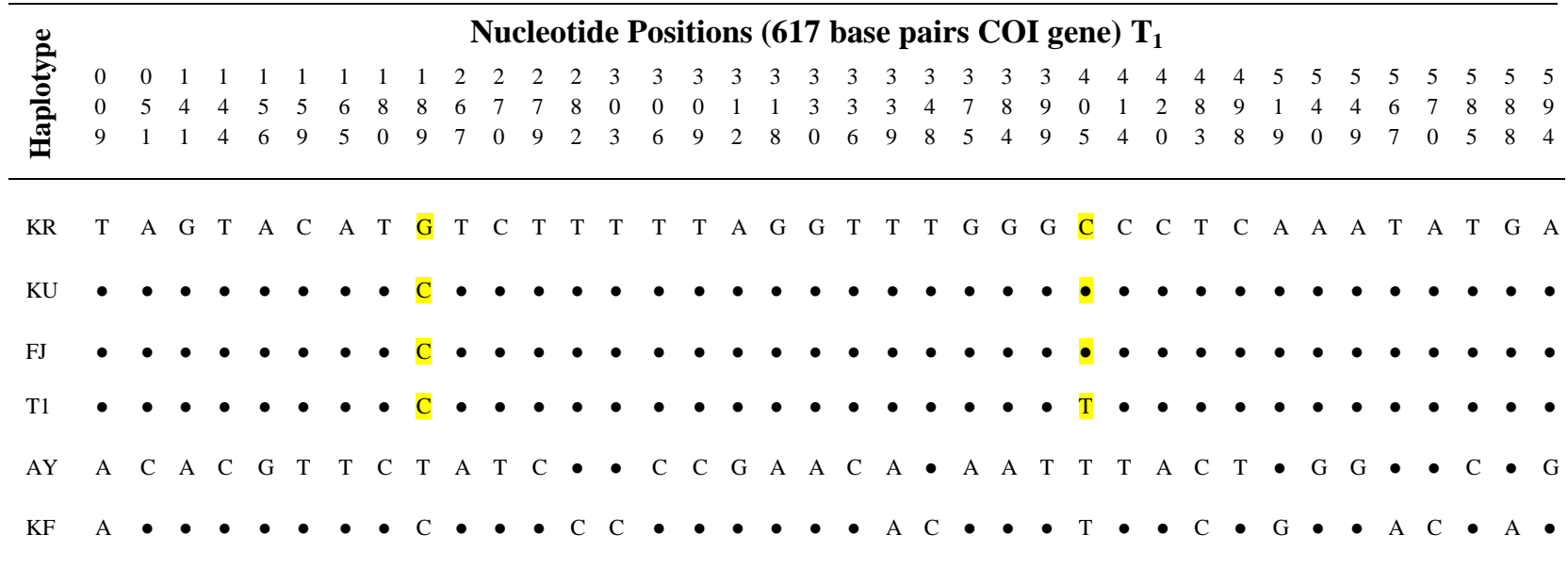

\section{Nucleotide Positions (857 base pairs D-loop gene) $T_{2}$}

\begin{tabular}{ccccccccccc} 
Haplotype & 103 & 188 & 189 & 244 & 271 & 439 & 512 & 535 & 628 & 746 \\
\hline $\mathrm{KU}$ & $\mathrm{T}$ & $\mathrm{T}$ & $\mathrm{T}$ & $\mathrm{C}$ & $\mathrm{G}$ & $\mathrm{T}$ & $\mathrm{A}$ & $\mathrm{T}$ & $\mathrm{G}$ & $\mathrm{C}$ \\
$\mathrm{KR}$ & $\bullet$ & $\bullet$ & $\bullet$ & $\bullet$ & $\bullet$ & $\bullet$ & $\bullet$ & - & $\mathrm{G}$ & $\mathrm{A}$ \\
$\mathrm{T} 2$ & $\mathrm{C}$ & - & - & $\mathrm{T}$ & $\mathrm{A}$ & $\mathrm{C}$ & $\mathrm{G}$ & $\mathrm{T}$ & $\mathrm{A}$ & $\mathrm{A}$
\end{tabular}

Where KR = KR150863.1; KU = KU878410.1; FJ = FJ440622.1; T1 = Lake Telabak COI (current study); AY = AY662781.1; KF = KF771234.1; T2 = Lake Telabak D-loop (current study); - = Nucleotide Gap;

$\bullet=$ represent identical nucleotide with $1^{\mathrm{ST}}$ haplotype in the list

\section{Phylogenetic Relationships}

The neighbour-joining tree showed that Lake Telabak Cichla spp. are closer to Cichla ocellaris as shown in the Figure 3 below. 


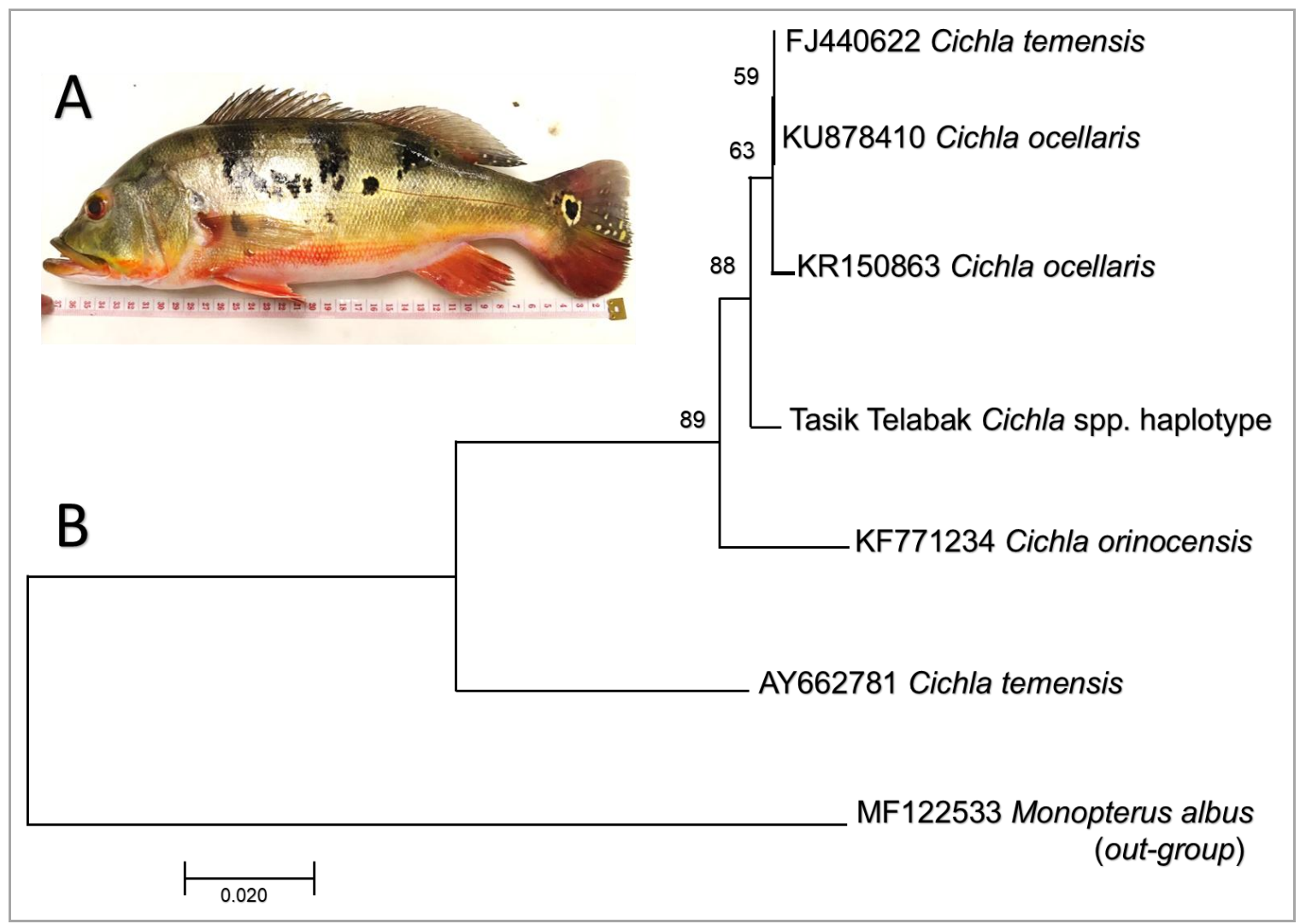

Figure 3. A: Sample of Cichla spp. collected from Lake Telabak B: Molecular phylogenetic analysis of COI gene of Cichla spp. by Maximum Likelihood method. The evolutionary history was inferred by using the Maximum Likelihood method based on the HKY model. The tree with the highest log likelihood (-1481.81) is shown. The percentage of trees in which the associated taxa clustered together is shown next to the branches. Initial tree(s) for the heuristic search were obtained automatically by applying Neighbor-Join and BioNJ algorithms to a matrix of pairwise distances estimated using the Maximum Composite Likelihood (MCL) approach, and then selecting the topology with superior log likelihood value.

\section{DISCUSSION}

Lake Telabak serve a significant role for the people around the lake. For the serenity, diversity of aquatic life especially fishes, and the strategic location, the government has launch a special program to boost the economy of villagers through the development of the lake. Villagers are given subsidiary to start freshwater fish culture using cage system in the lake. Other than that, the lake was also being promoted as recreational spot where kayak and fishing become the main activities. From this study, we recognize the present of peacock bass from the lake, which is not native to Malaysia. Recent studies show that COI gene of mitochondrial DNA barcoding method is a very useful way to identify and traced the taxonomy and origin of some invasive species (Granato et al., 2019; Golani et al., 2019). Single haplotype (T1 COI and T2 D-loop) obtained in this recent study is a clear indication that Cichla spp. in Lake Telabak has a single maternal origin and introduction. This finding might not reflected the mechanism and channel for peacock bass introduction. However, from personal communication with 
the villagers, they claimed that anglers come to Lake Telabak to fish Asian snakehead fish, Channa argus, which are among the main fish species present in the lake. Eventually their desire for more fishing excitement has encourage them to introduce peacock bass into the lake. Chong et al. (2010) and Barroco et al. (2017) described peacock bass as a good sport fish. The modus operandi of introduction of peacock bass was also similar in Malaysia like in Raban Lake (Desa and Aidi, 2013), Kapal Tujuh Lake (Saat et al., 2014), Temenggor Lake (Yap et al., 2016), Kampar River (Tan and Sze, 2017; Ng et al., 2018) and Timah Tasoh Dam (Zulkifli, 2017) in West Coast of Peninsular Malaysia.

Phylogenetic relationship and BLAST results of the current study confirm that Cichla spp. populations introduced to Lake Telabak belong to the $C$. ocellaris (KU878410 and KR150863). Hence, the origin of these two sequences are unknown as they were directly submitted to the genebank. Moreover, current study sequence also matched with $C$. temensis (FJ440622) that were originated and sampled from Manaus, Novo Airão, Tapajós and Tefé of Amazonas and Parà states of Brazil (Ardura et al., 2010). Knowledge about the origin and taxonomy of invasive species could help in understanding the biology of these species. Discovery of $C$. ocellaris in the current study is a milestone for careful investigation on the negative effects and consequences of this species based on the previously invaded habitat around the globe with their general role in biodiversity. For decade, studies on introduction $C$. ocellaris indicated a negative effects on local fish species in environments where it invaded (Pinto-Coelho et al., 2008; Pelicice and Agostinho, 2009; Rahim et al., 2013). Previous discovery of the fish population in Lake Redonda from 1989 to 1990, documented that many local fish species such as Metynnis cf. roosevelt, Cheirodon spp., Crenicichla lepidota, Astyanax bimaculatus, Hoplias malabaricus, and Cichlasoma bimaculatum extinct after the introduction of $C$. ocellaris (Molina et al., 1996). Recently, Menezes et al. (2012) reported that introduction of $C$. ocellaris in the coastal Lakes of Rio Grande do Norte is reducing native fish abundance with a negative impact on their diversity.

For now, it is difficult to measure the impact of $C$. ocellaris in Lake Telabak since there were no published records on species biodiversity in the lake before this. However, previous studies in Brazil and Puerto Rico reported how invasive Cichla spp. established and their continuous impact on reducing the native fishes population (Pelicice and Agostinho, 2009; Britton and Orsi, 2012; Sharp et al., 2017). This shows how these species becoming wide spread and more successful in occupying the newly habitat around the world. These could be a reasons that knowledge of genetic diversity and taxonomy is necessary for monitoring invasive Cichla population (Oliviera et al., 2006; Golani et al., 2019). Also, C. ocelleris are highly prolific and are associated with multiple spawning producing 2000-3000 eggs per brood (Gamero and Braga, 2004; GISD, 2019). As such, they wipe out small sized invertebrate-feeding fishes resulting in accumulation of large number of mosquito larvae around the lake and causing mosquito related diseases (Zaret and Paine, 1973). This could affect the fishing activities in the lake especially during the late and early hours of the day. Furthermore, studying $C$. ocellaris regarding prey, feeding and reproduction behaviour in their natural habitat might aid in discovering a common prey in Lake Telabak that might be at higher risk and first target. 


\section{CONCLUSION}

Our research revealed that invasive species peacock bass population in Lake Telabak were highly identified as $C$. ocellaris, with single introduction pattern. No record found regarding the origin of these sequence matched, but origin might be traced to C. temensis that originated from Manaus, Novo Airão, Tapajós and Tefé of Amazonas and Parà states of Brazil. This findings will contribute and enhance better understanding of Cichla spp. In order to preserve and guarantee the safety of biodiversity in the lake, it is highly recommended that further study should focus on the continuous diversity documentation and observation of native aquatic species in the lake. This will aid for better understanding on the impact of Cichla spp. introduction in the lake.

\section{ACKNOWLEDGEMENT}

The authors would like to thank Najlaa Nawwarah Rusli and Nurul Izzati Mohd Razif for samples collection. Our sincere acknowledgement goes to the Fundamental Research Grant Scheme (FRGS), Ministry of Higher Education (Malaysia) for supporting a part of this research under grant FRGS/1/2018/WAB13/UNISZA/02/2.

\section{REFERENCES}

Agostinho, A.A.; Thomaz S.M. and Gomes L. C. (2005). Conservation of the biodiversity of Brazil's inland waters. Conserv. Biol., 19: 646-652.

Ahmad-Syazni, K.; Khaleel, A.G.; Norshida, I.; Connie, K.; Nguang, S.I. and Ha, H.C. (2017). Population structure of swamp eel Monopterus albus in East Coast of Peninsular Malaysia inferred from 16S mitochondrial DNA. World Appl. Sci. J., 35, 1392-1399.

Ang, K. (1989). The status introduced fish species in Malaysia. Exotic Aquatic Organism in Asia, 71-82.

Ardura A.; Linde, A.R.; Moreira J.C. and Garcia-Vazquez E. (2010). DNA barcoding for conservation and management of Amazonian commercial fish. Biol. Conserv., 143: 1438-1443.

Barroco, L.S.A.; Freitas, C.E.C. and Lima, Á. C. (2017). Estimation of peacock bass (Cichla spp.) mortality rate during catch-release fishing employing different postcapture procedures. Braz. J. Biol., 78: 195-201.

Britton, J.R. and Orsi, M.L. (2012). Non-native fish in aquaculture and sport fishing in Brazil: Economic benefits versus risks to fish diversity in the upper River Parana Basin. Reviews in Fish Biology and Fisheries, 22: 555-565.

Callaway, R.M. and Maron, J.L. (2006). What have exotic plant invasions taught us over the past 20 years? Trends Ecol. Evol. 21: 369-374.

Chong, V.; Lee, P. and Lau, C. (2010). Diversity, extinction risk and conservation of Malaysian fishes. J. fish Biol., 76: 2059-2066. 
Department of Fisheries Malaysia (2010). Annual Fisheries Statistics. Jabatan Perikanan Malaysia. Putrajaya, Malaysia.

Desa, S. and Aidi, D. (2013). A proposed model of fish distribution in shallow lake based on feeding behaviour of fishes in Raban Lake. Conference: UMTAS 2013: The $12^{\text {th }}$ International UMT Annual Symposium, At Terengganu, Malaysia.

Dudgeon D. (2003). The contribution of scientific information to the conservation and management of fresh water biodiversity in tropical Asia. Hydrobiologia, 500: 295314.

Fazhan, H.; Waiho, K. and Ikhwanuddin, M. (2017). Non-indigenous giant mud crab, Scylla serrata (Forskål, 1775) (Crustacea: Brachyura: Portunidae) in Malaysian coastal waters: a call for caution. Mar. Biodivers. Rec., 10: 1-7.

Fragoso-Moura E.N.; Oportob, L.T.; Maia-Barbosab, P.M. and Barbosa F.A.R. (2016). Loss of biodiversity in a conservation unit of the Brazilian Atlantic Forest: The effect of introducing non-native fish species. Braz. J. Biol., 76: 18-27.

GISD, Global Invasive Species Database (2019). Species profile: Cichla ocellaris. Invasive Species Specialist Group, Gland, Switzerland. Available: http://issg.org/ database/species/ecology.asp?si=982\&fr=1\&sts=sss\&lang=EN. Accessed October, 2019.

Golani, D.; Sonin, O.; Snovsky, G.; David, L. and Tadmor-Levi, R. (2019). The occurrence of the peacock bass (Cichla kelberi Kullander and Ferreira 2006) in Lake Kinneret (Sea of Galilee), Israel. BioInvas. Rec., 8 (in press).

Gomiero, L.M. and Braga, F.M.S. (2004). Feeding of introduced species of Cichla (Perciformes, Cichlidae) in Volta Grande reservoir, River Grande (MG/SP). Braz. J. Biol., 64: 613-624.

Granato, A.; Negrisolo, E.; Bonomi, J. and Zulian, L. (2019). Recent confirmation of a single haplotype in the Italian population of Vespa velutina. Biol Invas., 21: 2811-2817.

Gubiani, É.A.; Ruaro, R.; Ribeiro, V.R.; Eichelberger, A.C.A.; Bogoni, R.F.; Lira, A.D.; ..., and da Graça, W.J. (2018). Non-native fish species in Neotropical freshwaters: how did they arrive, and where did they come from? Hydrobiologia, 817: 57-69.

Ha, H.C.; Nguang, S.I.; Zarizal, S.; Komilus, C.F.; Norshida, I. and Ahmad-Syazni, K. (2017). Genetic diversity of kampung chicken (Gallus gallus domesticus) from selected areas in East Coast Peninsular Malaysia inferred from partial control region of mitochondrial DNA. Malays. Appl. Biol., 46, 63-70.

Hajibabaei, M.; Janzen, D.H.; Burns, J.M.; Hallwachs, W. and Hebert, P.D.N. (2006). DNA barcodes distinguish species of tropical Lepidoptera. Proc. Natl. Acad. Sci., 103: 968-971. 
Hasegawa, M.; Kishino, H. and Yano T. (1985). Dating the human-ape split by a molecular clock of mitochondrial DNA. J. Mol. Evol., 22, 160-174.

Havel, J.E.; Kovalenko, K.E.; Thomaz, S.M.; Amalfitano, S. and Kats, L.B. (2015). Aquatic invasive species: challenges for the future. Hydrobiologia, 750: 147-170

Hebert, P.D.N., Stoeckle, M.Y.; Zemlak, T.S. and Francis, C.M. (2004). Identification of birds through DNA barcodes. PLoS Biol. E31, 2: 1657-1663.

Khaleel, A.G.; Ha, H.C. and Ahmad-Syazni K. (2019). Different population of Malaysia swamp eel in East and Southeast Asia inferred from partial $16 \mathrm{~S}$ mitochondrial DNA. Biosci. Res., 16: 01-09.

Khairul Adha, A.R. (2006). Peacock bass fish invasion in Malaysian waters. Research Bulletin, Faculty of Resource Science and Technology, Universiti Malaysia Sarawak, Vol. 1. June.

Kumar, S.; Stecher, G. and Tamura, K. (2016). MEGA7: Molecular Evolutionary Genetics Analysis version 7.0 for bigger datasets. Mol. Biol. Evol., 33: 1870-1874.

Lee, W.J.; Conroy, J.; Howell, W.H. and Kocher, T.D. (1995). Structure and evolution of teleost mitochondrial control regions. J. Mol. Evol., 41: 54-66.

Li, Q.; Deng, J.; Chen, C.; Zeng, L.; Lin, X.; Cheng, Z.; ... and Huang, X. (2019). DNA Barcoding Subtropical Aphids and Implications for Population Differentiation. Insects, 11: 11.

Librado, P. and Rozas, J. (2009). DnaSP v5: software for comprehensive analysis of DNA polymorphism data. Bioinformatics, 25: 1451-1452.

Marques, A.C.P.B.; Franco, A.C.S.; Salgueiro, F.; García-Berthou, E. and Santos, L.N. (2016). Genetic divergence among invasive and native populations of the yellow peacock cichlid Cichla kelberi. J. Fish Biol., 89: 2595-2606.

Menezes, R.F.; Attayde, J.L.; Lacerot, G.; Kosten, S.; Souza, L.C.; Costa, L.S.; Van Nes E.H. and Jeppesen, E. (2012). Lower biodiversity of native fish but only marginally altered plankton biomass in tropical lakes hosting introduced piscivorous Cichla cf. ocellaris. Biol. Invas., 14: 1353-1363.

Molina, W.F.; Gurgel, H.C.B.; Vieira, L.J.S. and Canan, B. (1996). Ac, a o de um predador exo' geno sobre um ecossistema aqua'tico equilibrado, I Extinc, õ es locais e medidas de conservac, a o gene'tica. UNIMAR, 18: 335-345.

Nafis, S.; Saleh, K.M.; Itam, K. and Latiff, A. (2001). Biodiversity databases for Malaysian flora and fauna: An update. Proc. Internet Workshop. 21-23 February. National Institute of informatics, Tokyo, Japan; organised by Internet Research Committee (IRC) of Institute of Electronics, Information and Communication Engineers (IEICE) Japan and High Quality Internet Study Group (HQI) of information Processing Society of Japan (IPSJ). Pp.1-6. 
Ng, C.K.C.; Ooi, P.A.; Wong, W. and Khoo, G. (2018). Ichthyofauna checklist (Chordata: Actinopterygii) for indicating water quality in Kampar River catchment, Malaysia. Biodiversitas, 19: 2252-2274.

Novaes, J.L.C.; Caramaschi, E.P. and Winemiller, K.O. (2004). Feeding of Cichla monoculus Spix, 1829 (Teleostei: Cichlidae) during and after reservoir formation in the Tocantins River, Central Brazil. Acta Limnologica Brasileira 16: 41-49.

Paknia, O.; Rajaei S.H. and Koch, A. (2015). Lack of well-maintained natural history collections and taxonomists in mega diverse developing countries hampers global biodiversity exploration. Org. Divers. Evol., 15: 619-629.

Palumbi, S.R. (1996). Nucleic acid II: the polymerase chain reaction. In: Hillis, D.M., Moritz, G., Mable, B.K. (Eds.), Molecular Systematics. Sinauer Associates, Sunderland, MA, pp. 205-247.

Pelicice, F.M. and Agostinho, A.A. (2009). Fish fauna destruction after the introduction of a non-native predator (Cichla kelberi) in a Neotropical reservoir. Biol. Invasions, 11: 1789-1801.

Pinto-Coelho, R.M.; Bezerra-Neto, J.F.; Miranda, F.; Mota, T.G.; Resck, R.; Santos, A.M.; Maia-Barbosa, P.M.; Mello, N.A.S.T.; Marques, M.M. and Barbosa, F.A.R. (2008). The inverted trophic cascade in tropical plankton communities: Impacts of exotic fish in the Middle Rio Doce Lake District, Minas Gerais, Brazil. Braz. J. Biol., 68: 1025-1037

Rahim, K.A.A.; Esa, Y. and Arshad, A. (2013). The influence of alien fish species on native fish community structure in Malaysian waters. Kuroshio Sci., 7: 81-93.

Reid, A.J.; Carlson, A.K.; Creed, I.F.; Eliason, E.J.; Gell, P.A.; Johnson, P.T.J.; ..., and Cooke, S.J. (2018). Emerging threats and persistent conservation challenges for freshwater biodiversity. Biol. Rev., 1-25.

Reiss, P.; Able, K.W.; Nunes, M.S. and Hrbek, T. (2012). Color pattern variation in Cichla temensis (Perciformes: Cichlidae): resolution based on morphological, molecular, and reproductive data. Neotrop. Ichthyol., 10: 59-70.

Renno, J.F.; Hubert, N.; Torrico, J.P.; Duponchelle, F.; Nunez Robriguez, J.; Garcia Davila, C.; Willis, S.C. and Desmarais, E. (2006). Phylogeography of peacock bass Cichla monoculus in the upper Madeira (Amazon, Bolivia): evidence of incipient speciation. Mol. Phylogenet. Evol., 41: 503-510.

Saat, A.; Isak, N.M.; Hamzah, Z. and Wood A.K. (2014). Study of radionuclides linkages between fish, water and sediment in former tin mining lake in Kampung Gajah, Perak, Malaysia. Malay. J. Analy. Sci., 18: 170-177.

Sharp, D.M.T., De León, L.F.; González, R. and Torchin, M.E. (2017). Tropical fish community does not recover 45 years after predator introduction. Ecol. 98: 412424. 
Sparks, J.S. and Smith W.L. (2004). Phylogeny and biogeography of cichlid fishes (Teleostei: Perciformes: Cichlidae). Cladistics, 20: 501-517.

Tan, K.W. and Sze, K.Z. (2017). Determination of heavy metal concentration in fish species in Kampar mining lake, Perak state of Malaysia. Fresenius Environ. Bull., 26: 4202-4207.

Ward, R.D.; Zemlak, T.S.; Innes, B.H.; Last, P.R. and Hebert, P.D. (2005). DNA barcoding Australia's fish species. Philosophical Transactions of the Royal Society of London B: Biol. Sci., 360: 1847-1857.

Yap, S.K.; Muneera, I.; Syakir, M.I.; Zarul, H.H. and Widad, F. (2016). Stable isotopes approach to infer the feeding habit and trophic position of freshwater fishes in tropical lakes. Iranica J. Ener. Environ., 7: 177-183.

Yong, D.L.; Low, B.W.; Ang, A.; Woo, M. and Ho, C. (2014). Multiple records of aquatic alien and invasive species in diets of native predators in Singapore. BioInvasions Rec., 3: 201-205.

Zaret, T.M. and Paine, R.T. (1973). Species introduction in a tropical lake. Sci., 182: $449-455$.

Zulkifli, A.S. (2017). Peacock bass is taking over native waters in Timah Tasoh Dam in Padang Besar, Perlis, Malaysia. https://www.nst.com.my/news/nation/2017/04/231 346/alien-fish-invasion peacock-bass-taking-over. Accessed 12/05/2019. 